\title{
Free Cortisol Measurement
}

National Cancer Institute

\section{Source}

National Cancer Institute. Free Cortisol Measurement. NCI Thesaurus. Code C88113.

The determination of the amount of free, unbound cortisol present in a sample. 